\title{
Yuval Levavi* \\ The Neo-Babylonian Empire: The Imperial Periphery as Seen from the Centre
}

https://doi.org/10.1515/janeh-2019-0003

Published online July 27, 2020

Abstract: The paper examines the cuneiform evidence from sixth-century Babylonia (and beyond) for information on the form and aims of Neo-Babylonian imperial rule over its western provinces. While new texts, which hitherto have not been considered in this context, can be brought to bear on the issue, direct evidence from these provinces is still scarce. These documents will thus be supplemented by drawing on the rich information concerning state institutions and resource extraction in the imperial centre. It is argued that in the first half of the Neo-Babylonian period, until ca. $585 \mathrm{BCE}$, Babylonian imperial rule in the western periphery can be conceptualized primarily as a straightforward exploitative tributary regime. From about the mid-reign of Nebuchadnezzar onwards, however, there is a shift towards a more sustainable resource extraction through the creation of stable pockets of Babylonian presence in the periphery. This diachronic shift was meant to steady and organize the initial ad hoc Babylonian approach. These measures, however, did not prevail, and the chaotic years which followed the 43 years reign of Nebuchadnezzar illustrate the fragility of the relatively short-lived Babylonian imperial age.

Keywords: Babylonian Empire, Babylonian temples, Habur, Neo-imperial rule, Tyre

\section{Introduction}

This paper examines the way in which the Neo-Babylonian monarchs exercised their domination outside the heartland of Babylonia. ${ }^{1}$ Given the scarcity of

\footnotetext{
1 An initial draft of this paper was written under the auspices of the 'Imperium and Officium' project, led by Michael Jursa, and financed by the Austrian Science Fund FWF at the University of Vienna and presented in the 2014 SBL annual meeting in San-Diego. I wish to thank Rocio Da Rive and the anonymous reviewers for their valuable comments and suggestions, and to Shana Zaia for correcting my English. All errors and views are my own.
}

*Corresponding author: Yuval Levavi, Institut für Orientalistik, University of Vienna, Vienna, 1090, Austria, E-mail: yuval.levavi@univie.ac.at. https://orcid.org/0000-0003-4165-6666 
pertinent documentation, such as e.g. Neo-Babylonian royal archives and other state records (regarding taxation, local government, military aspects, etc.), ${ }^{2}$ we must turn our attention to the evidence offered by alternative sources. Some of these sources originate in the imperial periphery itself, but the present paper focuses primarily on the Babylonian temples and the ways in which imperial policy in the periphery is echoed in their rich archives. ${ }^{3}$

I argue that, in the first half of the Neo-Babylonian period, until ca. 585 BCE, Babylonian imperial rule in the western periphery was primarily a straightforward exploitative tributary regime. From about the mid-reign of Nebuchadnezzar onwards, however, there was a shift towards a more sustainable resource extraction through the creation of stable pockets of Babylonian presence in the periphery. This diachronic shift was meant to steady and organize the initial ad hoc Babylonian approach. These measures, however, did not prevail, and the chaotic years which followed the 43 years reign of Nebuchadnezzar illustrate the fragility of the relatively short-lived Babylonian imperial age.

I first discuss the transition between the Neo-Assyrian and the Neo-Babylonian Empires, and the extent to which the Neo-Assyrian Empire can serve as a model for the Neo-Babylonian period. I then turn to cuneiform sources, starting with a survey the (relatively scares) Babylonian royal sources. The main section of this paper then focuses on the evidence for the activity of Babylonian temples in the periphery as reflected in the temple archives. This includes the agricultural ventures of the Ebabbar temple in the Habur region and the presence of Babylonian workforces, mainly of the Eanna temple, in the Phoenician city of Tyre. Finally, I turn to the indirect evidence from Babylonia proper and the impact of imperial rule on the economy of the core region of Babylonia.

2 This is contrasted of course against the famous State Archives of Assyria, one of the richest and most impressive sources from the Ancient Near East. For the (mostly unpublished) archive from the South Palace of Nebuchadnezzar, see Jursa 2005: 60, 2007; Pedersén 1998, 2005a, 2005b, 2009. For the latest summary and discussion, see Alstola 2020, esp. pp. 60-63. In the context of first millennium scholarship, the "state" in "state archive" (and similar phrases) stands for "royal/palace/ court," and is often contrasted with private and/or temple archives, context, etc. This convention is maintained in the present paper. The complex bureaucratic interaction between the Babylonian court and the major temples, as well as questions of institutional self-identification, have been dealt with extensively in recent years; e.g. Kleber 2008; Levavi 2018; Still 2019; Waerzeggers 2014. 3 Given the framework of this paper and its focus on the Babylonian sources, the destruction of the temple in Jerusalem lies mostly beyond the scope of the discussion below. For a brief assessment of the events in Judah and historical context, see the penultimate paragraph in the conclusion and note 61 below. 


\subsection{Historical Background}

When one envisions the Neo-Babylonian Empire, the image of the entire Fertile Crescent comes to mind; from the Persian Gulf at the south-east, up to modern day Turkey in the north, and back south to the southern Levant and the Mediterranean Sea. Before examining the imperial domination over these territories, a brief discussion concerning the origins of this empire is necessary. ${ }^{4}$

The first Neo-Babylonian king, Nabopolassar, denounced the Assyrian claim over Babylonia and declared himself king of Babylon in 626 BCE. ${ }^{5}$ The Assyrians, however, did not easily give up on their imperial dream. It was only in 612 BCE that the Assyrian capital Nineveh fell. Following the death of the Assyrian king Sîn-šar-iškun at this battle, his son Aššur-uballit, who was never himself officially crowned king of Assyria, ${ }^{6}$ led what remained of the Assyrian army until their final annihilation three years later (609 BCE) at Harran. Following this final defeat of the Assyrians, the Babylonians now faced the Egyptians on the shores of the Euphrates; the latter temporarily filled the vacuum left by the Assyrians in the west. In 605 BCE, Nebuchadnezzar, still as crown prince, led the Babylonian army in a campaign that drove the Egyptian forces out of Syria, thus establishing Babylon's domination over the Levant. ${ }^{7}$ Nebuchadnezzar officially took over the Babylonian throne about a year later, following the death of Nabopolassar. He subsequently continued to secure the empire in the west and by the middle of his reign, some 40 years after the empire's foundation, the Neo-Babylonian Empire made the transition from aggressive growth towards consolidation. ${ }^{8}$

4 Recent treatments of the background and formation of the Neo-Babylonian Empire can be found in Fuchs 2014; Jursa 2014b, and see also Levavi 2018: 15-18 focussing on the “formative phase", i.e. until the mid-reign of Nebuchadnezzar.

5 The traditional perception of the Babylonian chronicles as straightforward dry reports is being challenged. Recent scholarship stresses the complexity of perspectives reflected in the different Babylonian chroniclers by contextualizing individual chronicles; see e.g. Brinkman 1990, Levavi in press; Waerzeggers 2012, 2015; Zawadzki 2010. Yet this fine-tuned, contextualizing approach does not negate the fact the chronicles should still be considered a reliable source as regards political history in the general sense. The following survey is largely based on the traditional history of the Neo-Babylonian Empire as reflected in the chronicles.

6 See Radner 2002: 17-18, 2019, and §3.1below.

7 The domination, however, was neither complete nor stable for several years thereafter; see Kahn 2018 for the Egyptian-Babylonian interaction, especially during the reign of Nebuchadnezzar.

8 M. Jursa (2014b) has adopted the term of crossing the Augustan threshold (used in the context of Roman history, see e.g. Münkler 2007: 72) to describe this process. The concept is further developed and illustrated with the example of the Nūr-Sîn family in Uruk in Jursa and Gordin 2018. Note, however, that while the Augustan threshold may be relevant from the internal (Urukean in this case) perspective, it is much more problematic in the overall context of imperial policy. As will be shown below, as part of the consolidation process, the Babylonians increased their investments and paid more attention to the imperial periphery rather than minimising thier presence. 


\subsection{State of the Question and Models of Transition}

There are two main traditional, but somewhat contradictory, perceptions of Neo-Babylonian imperial rule in the west. ${ }^{9}$ The first of these perceptions may be referred to as the succession of empires. According to this notion, the Babylonians simply took over the Assyrian empire and continued the latter's administrative practices. ${ }^{10}$ The second, superficial domination, perceives the Neo-Babylonian rule in the west as amounting to little more than yearly raids by the Babylonian army, levying tribute from vassal states, or simply taking as much booty as possible. In this view, only a few strategically-important cities were under permanent Babylonian control, namely Carchemish on the upper Euphrates, Harran on the Balīh, and Riblah on the Orontes (Vanderhooft 2003: 244). ${ }^{11}$

The succession of empires thesis is more a simplification than a specific argument. Given the scarcity of historical and archaeological data, the fact that there are basic similarities between the provincial systems of the earlier NeoAssyrian empire and later Achaemenid empire may suggest a relative continuity in the ways that the three empires exercised their domination. ${ }^{12}$ However, some key elements of the imperial structure in the Levant under the Neo-Babylonian monarchs were clearly different from those of the Neo-Assyrian period. Under the latter, for example, many of the western territories had been turned into Assyrian provinces directly administered by an Assyrian governor. ${ }^{13}$ Nebuchadnezzar, on the other hand, mentions the kings of i.a. Sidon, Tyre, and Ashdod in the Hofkalender,

9 For an overview of the subject, in the context of a discussion of Judah during the NeoBabylonian period, see Lipschits and Blenkinsopp 2003: vii-ix, and several studies in the same volume, e.g. Barstad's (p. 3-20), Sack’s (p. 221-234), Vanderhooft's (p. 235-262), and Betlyon's 2003 (p. 263-284). D. Vanderhooft's 1999 monograph discusses several of the questions confronted below. He too, although not as prominently, gives much attention to the southern Levant, and to Judah in particular. As will be argued below, we should be extremely careful when extrapolating the status of Judah to the rest of the western parts of the Neo-Babylonian Empire, if we should do it at all.

10 Notwithstanding the simplified and short phrasing above, an example for this view is advocated by R. Sack (2004, esp. pp. 83ff.).

11 For the strategic value of Riblah, see Da Riva 2008: 13-14.

12 There is certainly a high level of continuity from the Neo-Assyrian to the Neo-Babylonian periods as regards to many internal administrative aspects. This is best illustrated in the titles of many high Babylonian officials (e.g. mašennu, rab kāṣiri, ša pān ekalli), which have a clear Assyrian origin; see Da Riva 2013; Jursa 2010; Levavi 2018; Sack 2003: 89-90.

13 For the Neo-Assyrian empire and the west see Bagg 2011: 281-301 (and see the list of provinces in Table 4, pp. 430-431), Bagg, 2013. 
a building inscription commemorating the building of his palace, dating to ca. 597 BCE. ${ }^{14}$ Furthermore, although the exact date may be debated, it is generally accepted that the Assyrians withdrew their forces from the Levant around the 64030s. ${ }^{15}$ Consequently, when Nebuchadnezzar arrived in the west in 605 BCE, the region had been "Assyrian-free" for a quarter of a century. Some of the western Neo-Assyrian provinces were able to regain their status as (small) kingdoms during this gap. The hypothesis of unbroken continuity from Assyrian to Babylonian rule should therefore be discounted, at least in such general terms.

The second concept, superficial domination, is mostly based on the evidence, or lack thereof, for significant Babylonian presence in the west. Most of the discussion has focused on information from the land of Israel, ${ }^{16}$ and was strongly influenced by the notion of the "empty land" and the biblical narrative. ${ }^{17}$ In the last 20 years or so, however, increasing (positive) evidence for Babylonian attempts to establish tighter control over the western periphery have modified some traditional concepts. Some scholars are thus arguing against the notion of a Judean dark age during the Neo-Babylonian period (e.g. Barstad 2003; Blenkinsopp 2002; Lipschits 2011). While they accept a certain depopulation of Judah following the Babylonian campaigns, they advocate continuity and identify an ongoing administrative structure that they connect to the new Babylonian regime. ${ }^{18}$ Others, like A. Faust $(2007,2011)$, maintain that there is still no real evidence for a Neo-Babylonian province in Judah. Ultimately, despite some disagreements regarding the severity of depopulation and the relative weight assigned to each of the contributing factors (deportations, famine, etc.), all seem to agree that the archaeological picture is more complex than previously thought, and the different areas in Judah were affected in different ways. ${ }^{19}$

14 See the list of Levantine rulers in the Hofkalender of Nebuchadnezzar (EŞ 7834), column VII*: 23'-29' (according to the edition of Da Riva, 2013: 217).

15 On the last reference of Assyrians in the west (Assurbanipal, Asb A ix: 73-ix: 24, BIWA 77ff., v: 61-vi: 2, in 645 BCE) and the Assyro-Babylonian transition, see Eph'al 1979: 281-82; Kahn 2018: 66-69; Vanderhooft 2003: 236-37.

16 The land of Israel is the best known and studied area with relevance for the problem at hand. This is true both from the archaeological perspective as well as in historical scholarship; see Faust 2012, with previous literature.

17 For an overview of the Biblical material, see Barstad 2003; Oded 2003.

18 A good example would be the lion stamp seals, see Lipschits 2011: 62ff., and Lipschits and Vanderhooft 2014. For a concise summary of the main findings and interpretation in context, see Lipschits 2011: 73.

19 For a wider view of demographic processes in first millennium Juda, see Faust 2007; Lipschits 2011 (both with references to earlier literature). For a general Archaeological overview of the Neo-Babylonian period in the southern Levant, see Faust 2012; Killebrew and Steiner 2014. For specific (key) aspects and case studies, see e.g. Carter 2003; Fantalkin 2011, 2018; Lipschits 2003; Zertal 2003; Zorn 2003. 


\section{Royal Sources}

Let us now turn to the cuneiform sources whose part in the scholarly discourses reflected above was relatively minor. ${ }^{20}$ First, it must be stressed again that, apart from the mostly unpublished South Palace texts, ${ }^{21}$ cuneiform tablets from the Neo-Babylonian royal archive(s) are still waiting to be unearthed. Furthermore, we must bear in mind that Aramaic, which was written on perishable materials, may have also played a role in royal administration, meaning that the recovery of parts of the royal archive(s) is simply impossible (Jursa 2014a: 97$).^{22}$

Nonetheless, some Neo-Babylonian royal sources are available to us. Such, for example, are rock-engraved public inscriptions that were placed in strategic locations as propaganda; see Da Riva 2008, 2012a, 2012b, 2013a, 2013b. ${ }^{23}$ It is well known that Neo-Babylonian kings did not, for the most part, address political and military aspects in their public inscriptions. ${ }^{24}$ Nonetheless, and despite the absence of direct, unmitigated Babylonian narrativization of their imperial policy, the inscriptions themselves are in fact evidence for Babylonian presence in the Levant; especially the rock inscriptions of Nebuchadnezzar at e.g. Nahrel-Kelb and Wadi Brisa in Lebanon. While these inscriptions commemorate (though do not focus on) Nebuchadnezzar's military campaigns, and thus do not

20 This is not to say that cuneiform sources were completely ignored. This is especially true in the works of D. Vanderhooft, A. Bagg, and R. Sack, for example. Furthermore, the Babylonian chronicles were obviously crucial in any historical reconstruction regardless to discipline. Lastly, it should be noted that the scarcity of Neo-Babylonian cuneiform records from the land of Israel was certainly considered as important negative evidence in the scholarly discourse.

21 See note 2 for references.

22 Having said that, and while there was certainly wide use of now unrecoverable Aramaic written sources, I would not overstress the theoretical existence of such records. State officials, including royalty, used Akkadian on a daily basis as can be seen in their letters; see Levavi 2018 for several examples, especially No. 58-66 and appendix A for letters by royalties. Moreover, contemporary private letters were also written in Akkadian (Jursa, Hackl, and Schmidl 2014), testifying that cuneiform was in wide use and not restricted to temple-affiliated circles. Adding the epistolographic sources to the glimpses of state administration as seen in the South Palace archive precludes us from dismissing the possibility that cuneiform too played a major part in the NeoBabylonian state administration.

23 While the outwardly-projected image of the Neo-Babylonian kings naturally relates to the questions discussed in this paper, our focus is on the actual policy rather than the literary and visual forms in which imperial propaganda was shaped. The above-cited works of Da Riva have extensively dealt with these issues, as well several studies by D. Vanderhooft, e.g. 1999, 2003, 2018 (with previous literature), and Nevader 2015.

24 Exceptions may be found in some hints in Nebuchadnezzar's Brisa inscriptions (Da Riva 2012a, 2012b) and the in the Neriglissar cylinder on Cilicia (C011, see Da Riva 2013b: 135-137). 
necessarily constitute evidence for a steady Babylonian presence in the west, they nonetheless testify to the Babylonian wish to control the region and to ensure that the present and future inhabitants would by aware of their authority (Da Riva 2014). Additionally, the clustering of Nebuchadnezzar's inscriptions in Lebanon may point to a certain Babylonian perception of the empire's borders. The southern Levant beyond Lebanon was certainly under Babylonian control, and was a crucial stronghold and barrier against possible Egyptian aggression, but it may have been perceived more as a buffer zone than as an organic part of the empire. ${ }^{25}$

The rock inscriptions of Nabonidus (556-539 BCE) in Sela (Jordan) and al-Hāì't (Saudi Arabia), and the Tayma stele should be mentioned here as well. Much evidence for the Babylonian activity and presence in the Arabian Peninsula during the reign of Nabonidus was revealed in recent years by the German excavation in Tayma; these include both Akkadian and Aramaic inscriptions as well as archaeological data; see Eichmann, Schaudig, and Hausleiter 2006. To that we may add the inscription (and rock relief) from al-Haai'ț; see Schaudig 2016. Unfortunately, these sources are either heavily damaged or too short and not much can be gathered regarding their content. The same can be said about Nabonidus' inscription in Sela, ancient Edom, modern day Jordan; see Crowell 2007; Da Riva 2019. The suggestion to contextualise the Sela inscription with Nabonidus' Edom campaign (Lemaire 2003) seems reasonable, yet too little is known (and understood) regarding Nabonidus' activity in the transjordan; the extent and nature of the Babylonian rule over the region is thus still unclear. The work of the Spanish expedition in Sela (as well as of the German one in Tayma, for that matter) is still in progress and is sure to shed more light on the Babylonian activity in these areas in the upcoming years. For now, however, the present discussion is restricted to the northern and werstern priephery, mainly in the context of Nebuchadnezzar's reign.

Another type of royal source that should be looked at are the Neo-Babylonian building inscriptions commemorating the massive public construction projects undertaken throughout Babylonia. The importance of the Nebuchadnezzar's Hofkalender, establishing the existence of small kingdoms in the west, was already mentioned above (see note 14 above). In two other inscriptions (C41, C041), ${ }^{26}$ commemorating the building of the ziggurats of Babylon and Borsippa

25 This does not take into account the later royal inscription of Nabonidus in Tayma, and, more importantly in the present context, his rock inscription in Sela Jordan. On the possible context of the Sela relief see e.g. Da Riva 2019; Lemaire 2003: 287-288; Raz, Raz, and Uchitel 2001; Rubio 2009: 162, . For Nabonidus' inscriptions in Tayma, see e.g. Eichmann, Schaudig, and Hausleiter 2006; Livingstone 2005.

26 For the sigla, see Da Riva 2008. 
(respectively), Nebuchadnezzar again surveys the multiple contributors to these grand projects. From these inscriptions we can extract a rough layout of the empire's structure painted in very broad strokes. ${ }^{27}$

The core of the empire, Mesopotamia proper, consisted of three relatively well-defined main areas; a) Akkad: central and northern Babylonia, including Babylon itself and major urban centres such as Borsippa, Sippar, and Nippur, and some tribal regions (including some regions east of the Tigris); $b$ ) the Sealand: southern Babylonia, including the delta of the Tigris and Euphrates as well as the old Babylonian cities of Uruk and Ur; c) Assyria: northern Mesopotamia.

The western periphery is naturally harder to discern and the picture is much vaguer. Three areas are referred to in C41 and C041: Nēberti-Purattu (Upper Syria), Hatti ([north-west] Syria), and Eber-nāri (southern Levant). ${ }^{28}$ Furthermore, the two ziggurat inscriptions speak of governors (pihātu and šakkanakku officials) of Hatti and of Nēberti-Purattu, but of the kings (̌̌arru) of Eber-nāri. Also mentioned are the kings of the Upper and Lower Sea; the Upper Sea is the Mediterranean and the Lower Sea is the Gulf. The kings of the Upper Sea are those of Eber-nāri mentioned above. The kings of Lower Sea are harder to identify, but it may it may refer to kings in the Arabian Peninsula(?) and/or possibly Bahrain(?). ${ }^{29}$ Whatever the answer may be, there seems to have been a distinction between the immediate western peripheries, i.e. Syria, which was ruled by governors, ${ }^{30}$ while further lands in the southern Levant were ruled by local kings. This also fit the list of small kingdoms mentioned in the Hofkalender.

Unlike the Hofkalender, which can be dated around the seventh year of Nebuchadnezzar (598 BCE), the two ziggurat inscriptions cannot be dated with accuracy. The Etemenanki project in Babylon was initiated during the early years of Nebuchadnezzar, while the work on Eurmeiminanki in Borsippa started much later during his reign (Kleber 2008: 135, 161, respectively). The above layout can thus

27 The following description corresponds to the discussion in Da Riva 2012a, 2012b: 16-17.

28 Note that, in the chronicles, Hatti encompass the entire Mediterranean cost all the way south to the Philistine cost, i.e. including the area referred here as Eber-nāri.

29 The interaction between the Neo-Babylonian Empire and the Arabian Peninsula during the first millennium are complex and are not sufficiently understood. For Arabians in Babylonia, see Zadok 1981, 2013; for commercial aspects, see MacDonald 1997; for a general summery, especially of the reign of Nabonidus, see Magee 2014: 272-274.

30 There is not enough information regarding the identity of those governors and whether they were local or Babylonian officials; see Vanderhooft 2003: 244-247. 
can only serve as rough overview or a basic conceptual framework of ancient Near East as seen from the centre. ${ }^{31}$

Given the limitations of the royal sources discussed above, we may turn our attention to archival material, which forms the overwhelming majority of cuneiform records. The tens of thousands of tablets from the Neo-Babylonian period come from both private and temple archives. ${ }^{32}$ For the present context, the NeoBabylonian imperial rule, the known private archives are of less relevance. ${ }^{33}$ The two major temple archives of Eanna (Uruk) and Ebabbar (Sippar), on the other hand, can be mined for different aspects of the Neo-Babylonian rule in the western peripheries. Most, though not all, of the discussions below are based on these sources.

\section{Habur}

Although relatively close to Babylonia proper, the Habur region was affiliated with the land of Assyria and thus peripheral from a Babylonian perspective. ${ }^{34}$ The region was one of the first to come under Babylonian rule after the fall of Nineveh in 612 BCE. The Babylonian chronicle, for example, states that the people of Rașappu (about $150 \mathrm{~km}$ west of Nineveh) were brought before Nabopolassar to Nineveh (Grayson 1975 n. 3 [= Glassner 2004 n. 22]: 49), probably to take a loyalty oath. ${ }^{35}$

31 An interesting source in this respect is BM 92687, better known as the Babylonian Map of the World; see Horowitz 1998 20ff. (ch, 2). This unique bird's-eye sketch naturally places the city Babylon at the center. The city is crossed by the (Euphrates) river and around it we find Urarțu, Assyria, Dēr, Susa, Bīt-yākin (i.e. the Sealand), Habban, several unnamed cities, as well as the mountains, the canal, and the swamp. Yet, it must be stressed that the map should probably be dated to the eighth or seventh century and its schematic representation follows Mesopotamian cartographic convention (Horowitz 1998: 26-27). This means that its relevance to the question of Babylonian political rule over the western periphery is minor at best.

32 For a comprehensive survey of first millennium archival material, see Jursa 2005.

33 The situation is different for the Persian period, in which private archives are an important source for the interactions of many Babylonian families with the Persian authorities; see e.g. Waerzeggers 2010.

34 The pertinent sources are relatively abundant (comparing to the sources concerning Tyre discussed below), allowing for a more in-detail examination of the area. As a result, the following section will take a larger part in this study.

35 For the Ebabbar sources regarding Rașappu (= Rușāpu) during the late Neo-Assyrian and early Neo-Babylonian periods, see Da Riva 2002: 217ff. 


\subsection{Dūr-katlimmu}

Not far from Rașappu, south-west along the Habur River, lay the city of Dūrkatlimmu. ${ }^{36}$ Several of the cuneiform documents unearthed in the excavations of Dür-katlimmu are dated between the very end of the Neo-Assyrian period and the early years of the Neo-Babylonian Empire, shedding light on the critical Assyrian/ Babylonian transitional phase. ${ }^{37}$ Unlike the major Assyrian cities, such as Assur and Nineveh, there is no indication of military activity in Dūr-katlimmu. ${ }^{38}$ Perhaps, as in the case of Rașappu, the people of Dūr-katlimmu were quick to pledge their loyalty to Nabopolassar, thus ensuring peace for their city. Be that as it may, from an administrative point of view, there seems to have been a kind of intermediate stage between the fall of Nineveh and the time when the Babylonian bureaucracy replaced that of Assyria.

This transitional phase may be illustrated by SH 199, a Neo-Assyrian legal dispute. The obverse of the text is heavily damaged and not much can be said regarding the details of the case. The tablet is dated to the otherwise unknown eponym Ša-ilèi, yet prosopography makes it clear that the relevant timeframe is the final years of the Neo-Assyrian period (Radner 2002: 17-18). Important in this context is the adê-oath (1.10), which peculiarly invokes the crown prince (adê mār šarri), rather than the king himself. Radner (ibid., 2019) convincingly argues that this narrows down the time frame to between 612 and 609 BCE, since, officially, there was no Assyrian king at that time. Aššur-uballiț is usually considered to have been the last Neo-Assyrian king, who ruled from Harran following the fall of Nineveh in 612 and the death of his father, king Sîn-šar-iškun. This narrative, however, is based solely on the Babylonian chronicle (Grayson 1975 n. 3), and while it is certainly highly reliable as far as the overall narrative, it seems to get one significant detail wrong. An Assyrian king must be crowned in the temple of Aššur. And since the city of Aššur itself fell already in 614 (Grayson 1975 n. 3: 16ff.), Aššuruballit was never officially made king of Assyria. This is a detail that a later Babylonian chronicler could easily have gotten wrong, but not a contemporary Assyrian invoking an adê-oath in a legal document. Combining the adê-oath with prosopography gives us a solid timeframe of 612-609 BCE, i.e. after the fall of Nineveh, but prior to the final Assyrian defeat in Harran. It may be significant in this respect that the first witness, and thus of the highest rank of those listed in $\mathrm{SH}$ 199, is a certain Iadi'-il, who bears the title "Lord of the city" (bēl āli). The position

36 Note, for example, the mention of a certain Bēl-ēreš of Rașappu ( $\left.{ }^{\text {kur }} r a-s ̣ a-p a-a-a\right)$ in the DūrKatlimmu text SH 122, as an indication for the interaction between those cities.

37 For the cuneiform texts from Dūr-katlimmu, see Radner 2002.

38 Kühne 1995: 83. For the continuity of ceramic traditions, see Kreppner 2008a, 2008b. 
of this municipal official fits well into the picture of Dūr-katlimmu resorting to selfgoverning at this intermediate period. This is also the context in which we must understand the use of a local eponym.

Four other Dūr-Katlimmu texts, recovered in the Red House (SH 37-40), were written about 10 years after SH 199 and represent the next phase of Babylonian rule. ${ }^{39}$ The texts are written in the Neo-Assyrian dialect with the corresponding Neo-Assyrian script, and draughted in the Neo-Assyrian text format. They mention several Assyrian officials (some attested prior to 612 BCE) but no Babylonian officials. Despite these Neo-Assyrianisms, the scribes dated the texts to the second, third and fifth years of Nebuchadnezzar (603-600 BCE). This means that the old Assyrian eponym dating system had been abandoned and the new Babylonian date formula, counting the regency years of the present monarch, was adopted by the local scribes and administration.

The great political shift of the time was certainly felt in the city of Dūr-katlimmu but life did not stop. Local officials were able to keep their positions and the Assyrian inhabitants along the Habur river kept doing things in their Assyrian ways. Adopting Babylonian dating practices, however, was naturally a secondary side-effect. Most significant was the acceptance of Nabopolassar's dominion over the land and the regular tribute, which was to be sent south to Babylon. The picture from these early years of the Babylonian rule is of a tributary model. With time, however, as will be discussed below, the Babylonians moved beyond simple resource extraction, and the second half of the Neo-Babylonian period is characterized by an increasingly tight control over the western periphery.

\subsection{The Habur Region in the Ebabbar Archive}

I now turn to the archive of the Ebabbar temple, temple of Šamaš in Sippar, and its activity in the Habur region. ${ }^{40}$ The Habur area is first attested in the Ebabbar archive in year 24 of Nebuchadnezzar's reign (580 BCE). This is more or less the mid-point of his 43-year reign (605-562 BCE), which, as noted, marked the consolidation phase of the Babylonian empire. The correlation between this turning point and the first reference to the Habur is not coincidental, but reflects the transition to a greater Babylonian presence in the periphery. The Ebabbar text CT 57, 214 mentions the Habur in the context of animal husbandry, stating that

39 On these texts see Becking 2002: 155-57; Brinkman 1993; Fales 1993; Kühne 1993; Postgate 1993; Radner 2002: 17-18.

40 The Habur dossier in the Ebabbar archive is treated in Jursa and Wagensonner 2014, on which the following discussion is based. 
sheep from the urur ha $a^{7 \star}$-bu-ru are sent to the Ebabbar temple as an offering to Šamaš. ${ }^{41}$ About 25 years later, early in the reign of Nabonidus, there are references to cattle of the Ebabbar kept in the Habur (VS 4, 36 and Nbn. 250, dated the second and seventh year of Nabonidus, respectively), as well as to the exploitation by the Ebabbar temple of vineyards (e.g. BM 74439 [= Jursa 1995 n. 43]; and CT 55, 9), and grain fields (e.g. BM 61541) in the Habur area.

From the fifth year of Nabonidus onwards (and probably even slightly earlier), the Ebabbar maintained two plough-teams in the Habur. One team was headed by a certain Šamaš-ahhēe-erība, who was working with his three sons and his brother. The head of the second plough-team, Lišir, was in charge of his brother and four other men..$^{42}$ Both plough-teams were supervised by an Ebabbar official named Šamaš-upahhir, whose activities in the area are recorded in a number of administrative texts and several letters. ${ }^{43}$

The cultivated lands were granted to the temple by the crown. Note, for example, the following lease contract and the way in which a plot of land of the Ebabbar temple is referenced:

Land, property of Šamaš (makkūr Šamaš), a royal grant (nidintu šarri), which is [along] the Habur river (BM 74439: 1; Jursa 1995: 142, No. 43).

In accordance with the Babylonian land for service system, the lease further states that the tenants had to provide corvée work and/or military service (Akk. ilku and urāšu) to the crown.

In addition to administrative notes and legal documents (see note 41), the Habur dossier contains several letters sent to Sippar by temple officials who were working at the Habur. These illuminate many of the problems that the temple encountered in the management of distant agricultural lands. ${ }^{44}$ Perpetual manpower shortage, a hallmark of institutional economy throughout the long sixth century (ca. 626-484 BCE), ${ }^{45}$ may be regarded as one of the main challenges that the Ebabbar temple faced in this respect. Under these conditions, the temple was in a constant struggle to fully exploit the potential of the land granted by the crown; note for example the following letter:

41 For the dating of CT 57, 214 to $24<$ Nbk>, see Jursa 1995: 223.

42 Both teams, as well as the animals at their disposal, are listed together for example in the undated text BM 75537 (= Jursa 1995 n. 3, pp. 17-18).

43 The administrative and legal records from the Habur dossier are listed in Jursa and Wagensonner 2014: 115-116. The pertinent letters are edited in the appendix.

44 On Neo-Babylonian administrative epistolography, see Levavi 2018, and especially pp. 176ff. (§5), dealing with main topics of correspondence.

45 See Jursa 2010a: 726 (and passim), Levavi 2018: 202-212 (and passim). 
Land, (viz.) the very plot allotted to Lī̌sir, is abandoned; he does not cultivate his field. Go and see with your own eyes how much land lies abandoned. Give seed, grain, and fodder to Šamašupahhir, so that the sowing is not delayed. (CT 22, 20 = Jursa and Wagensonner 2014: 112).

The names of neither the sender nor the addressee(s) are preserved, but it is clear that the missive was sent by a temple official from the Habur to the head(s) of the Ebabbar temple. Lišir, who is allotted the land, is one of the above-mentioned team-leaders working at the Habur. His supervisor, Šamaš-upahhir, is to deliver to him seeds, grain, and fodder, as he too was answerable for any delay in the work in the Habur. And though the reason for the abandonment of Lišir's plot is not specified, his inability to meet the temple's expectations should be seen in the context of the aforementioned manpower shortage.

In another (undated) text we find a list of seven men that were sent with Šamaš-upahhir to reinforce the temple's plough-teams. Although the text is not necessarily related to CT 22, 20 above, it illustrates the general context and the problems facing the temple's foremen in the Habur:

- [Ploughmen] who are to go with Šamaš-upaḩhir:

- Itti-Nabû-ī[nīa], an old man;

- Lū-ahū'a, his son, an adult worker;

- Arad-Bēl and Rēmūt-ili, his elder sons;

- Bunene-ibni, an old man;

- Šamaš-ahu-uṣur, an adult worker.

- Altogether seven men of/for Habur.

- Two plough oxen, one old ox, one cow. Altogether four heads of cattle and two donkey mares. Shepherds in Habur: Rēmūt-Bā'u...

- $\quad$ (BM 75601 = Jursa and Wagensonner 2014: 112-113)

Though at first sight BM 75601 seems to show that the temple was able to reinforce the teams with fresh blood, only two of the workers were in fact adult men fit for intensive agricultural labour. Two of the remaining four were old men, and the other two were not old enough to be referred to as adult workers. Moreover, one of the three oxen was an old ox ( $a$ lpu šìbi), which may have been an even more serious problem than that of the unfit human workers. To deal with the shortage of man and beast power, some land was outsourced and cultivated by sharecroppers (errēšu), rather than by temple personnel: ${ }^{46}$

... [In the past] when Šamaš-upahhir planted [one] kurru of vineyard, he barely managed to complete the task, while much of the land belonging to Bēl and Nabû was being planted. ... (this year) he does not have (enough) workers to build the enclosure (of the vineyard). Let the

46 For sharecroppers (errēšu) in the Eanna archive, see Janković 2013: 62-66. 
Lord send workers so that they can build the enclosure. ... The harvest of this year should have been allotted to (some) hired labourers to make them build the enclosure. (CT 22, 196 = Jursa and Wagensonner 2014: 114).

Resorting to hired labourers was by no means unique to the agricultural sphere. The same practice prevailed for other aspects of temple activity; most notably in the context of royal building projects to which the temples were obligated to contribute work forces. ${ }^{47}$ Time and time again, the temples were forced to supplement their own personnel (temple-serfs, širku) by paying hired-labourers to honour their work duties.

CT 22, 196 also reveals the involvement of other temples in the Habur alongside Ebabbar. The "land belonging to Bēl and Nabû" was land granted to Esagil, the temple of Bēl in Babylon, and to Ezida, the temple of Nabû in Borsippa.

From the royal perspective, the benefit of these land grants was threefold. First, by granting lands to the temples the crown created additional revenues (in taxes and imposts) from under-exploited areas. Additionally, the plots were saddled with military service and corvée duties benefitting the crown. Finally, by granting land to Babylonian institutions in peripheral areas, the palace created pockets of Babylonian presence outside Babylonia proper. Though the cultivators were not auxiliary military forces, their presence was nonetheless of some importance, even if on a mere declarative level. This may have been all the more welcome when, towards the end of the Neo-Babylonian period, the borders of the empire, especially in the north, were put under increasing pressure by the Persians. The following letter was written a few months before Cyrus conquered Babylon by Arad-Bēl, an Ebabbar official sent to inspect the work in the Habur. The "enemy" mentioned in the letter is the ever-closing Persian forces:

...When I said to Šamaš-upahhir, “(why) have you pressed the grape mash before my arrival,” [he replied], "we were afraid of the enemy, so [we have] pressed the grapes (already); but look, the rest has been dried.” (CT 22, 38 = Jursa and Wagensonner 2014: 115).

\section{Tyre}

The city of Tyre (Șūru) on the Lebanese coast is yet another example of the involvement of Babylonian temples, mostly the Eanna in Uruk, in this western part of the empire. ${ }^{48}$ The early Tyre dossier in the Eanna archive includes four texts, all

47 For the involvement of Neo-Babylonian temples in royal projects, see Beaulieu 2005; Levavi 2018: $176-186$.

48 As has been shown by K. Kleber (2008: 142-144), the attestations of Șūru in several NeoBabylonian archives indeed refer to the western city of Tyre on the Phoenician coast, rather than to a village of Tyrian exiles in Babylonian proper. 
written in Tyre during $14 \mathrm{Nbk}$ (591 BCE). The texts record deliveries of silver and barley (for wages), as well as iron tools being sent to the royal resident (qipu) of Eanna, who was (temporally) stationed in Tyre. The exact nature of the construction activity is unknown. Interestingly, however, it takes place at the same year Itto-Ba ${ }^{\text {a }}$ al III took the Tyrian throne, and the two episodes might be connected in some way. This modest involvement in Tyre, at any rate, amounted to neither steady nor massive Babylonian presence in the city. ${ }^{49}$

A second, slightly later, Tyrian dossier in the Eanna archive is dated to $(31+/)$ 38-41 Nbk. ${ }^{50}$ Adding the six texts from Sippar and the one from Nippur, the time frame stretches to $31 / 5 \mathrm{Nbk}^{51}-1 \mathrm{AM} .^{52}$ These documents record shipments of goods, salaries for temple serfs, and silver from Uruk to the west, as well as business transactions of temple officials in Tyre itself following the 13-year Babylonian siege of Tyre between $17 \mathrm{Nbk}$ and $30 \mathrm{Nbk}$ (588/7-575/4 BCE). ${ }^{53}$

The silver that Eanna sent to Tyre was used to pay the wages of hired labourers. The silver wages for hired labour model is well documented within Babylonia proper, ${ }^{54}$ and it is in fact similar to the outsourcing of agricultural work by the Ebabbar temple seen above. The Eanna texts also mention representatives of other Babylonian cities and temples: the temple administrator (šatammu) of the temple of Lugal-Marada in Marad (PTS 2992); the governor (šandabakku) of Nippur (GC 1, 94); the royal residents (qipu) of Ezida (in Borsippa), Emeslam (in Kutha), and the governors (̌̌ākin tẹmi) of Kiš and Dilbat (Eremitage 15474).

The (late) Eanna Tyre dossier, along with the few references in the Sippar and Nippur documentation, make it clear that the major Babylonian temples and cities maintained regular workforces on the Phoenician coast, and a heavy Babylonian presence must have been felt in Tyre. One text, PTS 3181, even mentions a new Babylonian settlement in the west, the "Town of the New Canal” (Āl-nāri-ešši), which may have served (and financed) the Babylonian garrison on the Phoenician coast (Van der Brugge and Kleber 2016). Like in the Ebabbar sources recording the Babylonian activity in the Habur region, the Tyre-related records reveal an intensified and steady

49 Kleber 2008: 144-45; Van der Brugge and Kleber 2016.

50 PTS 2516 (= Joannès RA 81: 153f.) was most probably written before $38 \mathrm{Nbk}$, but it can only be date to post $31 \mathrm{Nbk}$.

51 This is based on the dating of the Nippur text, Ni 361, to $31 \mathrm{Nbk}$, which requires collation; see Kleber 2008: 152f.435. Otherwise, the next dateable text is Nbk. 287, 35 Nbk.

52 For the list of all texts belonging to the "Tyre dossier" in the Eanna (Uruk) and Ebabbar (Sippar) archives, see Kleber 2008: 145ff.

53 For the 17-30 Nbk dating of the siege on Tyre, rather than 20-33 Nbk set by Katzenstein (1973: 325f.), see Van der Brugge and Kleber 2016.

54 For the Babylonian temples' strategies in managing their workforces, see Jursa 2015; Levavi 2018: 176-188. 
Babylonian presence in the west around the 30th regnal year of Nebuchadnezzar onward. This, again, fits well within the political-historical framework argued in the paper for the mid-Nebuchadnezzar watershed of the Neo-Babylonian imperial rule.

\section{Indirect Evidence: Economic Aspects in the Imperial Centre and its Reflection on the Babylonian Domination in the Periphery}

Finally, Babylonia proper provides indirect evidence on the imperial rule over the periphery. In its core, the Neo-Babylonian Empire established stability through an institutional framework that led to an economic boom (Jursa 2010a: 796-797). Central and southern Babylonia, especially along the Euphrates axis, experienced demographic growth, increased urbanization, monetization, and a rise in per-capita production..$^{55}$ One of the clearest manifestations of this prosperity is the numerous and ambitious building projects undertaken by the Neo-Babylonian kings. All over Babylonia they built and rebuilt temples, palaces, city walls, water courses and irrigation infrastructures, from Ur and Uruk in the south to Sippar and Opis in the north. Above all, the Babylonian kings concentrated on their capital city. From the biblical tower of Babylon to the mysterious hanging gardens, the Neo-Babylonian kings made Babylon a city that fired the imagination of people for the next 2500 years..$^{56}$ The question should be asked then, what and who made it all possible? Simply put, the "what" was (notably) money extracted from the newly acquired territories, and the "who" was local labour.

In a basalt stele found in Babylon (Schaudig $2001 \S 3.3^{\mathrm{a}}$, pp. 514ff.), Nabonidus states that he awarded $3000 \mathrm{~kg}$ of silver and about $160 \mathrm{~kg}$ of gold to the three main temples of Babylonia: the temples of Marduk (Esagil in Babylon), Nabû (Ezida in Borsippa) and of Nergal (Emeslam in Kutha).$^{57}$ Nabonidus further specifies that the origin of this huge amount of silver and gold was:

55 The sources and figures are thoroughly discussed in Jursa 2010a.

56 For a survey of the royal building activity as the kings have portrayed it in their royal inscriptions, see Da Riva 2008: 109ff. For the Neo-Babylonian public projects based on the Eanna temple archive, see Kleber 2008: 133ff. For the logistic and administrative apparatus of the temples and their interaction with the state in these building projects, see Beaulieu 2005 and Levavi 2018: 176-186. Recently, there have been several suggestions to re-date some of what were previously thought to be Neo-Babylonian strata to later Persian dates. See, for example, André-Salvini 2013. While there seems to be merits to some of these suggestions (see e.g. Oelsner, 2017 review of André-Salvini 2013), this does not change the overall picture of a massive increase in state initiated building and infrastructure projects undertaken by the Babylonian kings during the late seventhearly sixth centuries.

57 For the divine triad of Marduk, Nabû, and Nergal, see Baker 2002. 
A gift of submission taken from the riches of the lands, the property of the mountain ranges, the possessions of all the cities and the gifts of homage made (to me) by (vassal) kings. (translation: Jursa 2014b: 137).

Apart from what was hoarded in the palace, the money and spoils taken from subordinate kings were passed on as royal gifts to the temples. The temples spent the silver and gold on wages for temple serfs (širku) and hired labourers (agru) employed on building projects initiated by the state. ${ }^{58}$ The sources show that a considerable part of the building activity in Babylonia and beyond was managed by the temples that served as extended governmental agencies.

Admittedly, our sources, which are mostly drawn from the temple archives, present us with a somewhat partial picture in this respect. Be that as it may, the notion that the tower of Babel was built through the labour of poor deported Judeans and other Levantine exiles and war prisoners is not corroborated by the sources. This, incidentally, is also supported by the Al-Yahudu/Našar/Bit-Abiram tablets (Pearce and Wunsch 2014), in which we find small communities of deportees settled in the hinterlands around Nippur (and southwards to Uruk). Deportation and settlement were a rural phenomenon in Babylonia, not an urban one. ${ }^{59}$

The cuneiform records from Babylonia proper show then that the influx of spoils from the west was re-invested into the local Babylonian economy, boosting the empire's heartland. At the same time, this economic boom necessitated a considerable expansion in the number of working hands. And since the working hands were, for the most part, Babylonian hands, one of the main effects of these economic settings was the chronic shortage of manpower experienced by the temples. Generally speaking, communities of deportees from the west were not

58 See Levavi 2018: 176-186. This mechanism basically parallels what we have seen in the context of the temples' activity in Tyre, as well as the agricultural works in the Habur.

59 That is not to say that the newly-occupied territories in the west did not share the imperialistic building effort; on the contribution of subdued regions in the grand building endeavours in Babylon, see Beaulieu 2005 and Da Riva 2018 (with references and further literature). Furthermore, newcomers certainly occupied the streets of Babylonian urban centers. The ration lists from the South Palace in Babylon and the Arih dossier from Sippar testify to the presence of Judean exiles in these cities; see most recently Alstola 2020. There is further evidence for individuals and small groups of foreigners involved in public projects. One example would be Egyptians who are mentioned in the Ebabbar archive in this context; see Hackl and Jursa 2015, and especially the examples of "free men" in p. 162. Furthermore, in YBC 4022, to be published by Jursa and Zadok 2020, we find that, once we are away from the temple precincts, the Babylonian streets and markets (of Uruk in this case) were crowded with foreigners. Yet in the context of organized workforces and communities, these are found in the rural, rather than in the urban, centers. 
incorporated into the temples' workforces. Instead, they were re-settled by the state in under-exploited agricultural areas.

\section{Conclusions}

When the Babylonians arrived west of the Euphrates in 605 BCE, the former Assyrian arrangements were no more. Some former Assyrian provinces had regained autonomy, restoring their own kings. Nebuchadnezzar allowed them to retain this status as long as his demands for yearly tribute was met. The evidence from the near periphery in the north (Habur) and from the far periphery in the west (Tyre) shows that, until the middle of Nebuchadnezzar's reign, the Babylonians focused mainly on securing their core territories and did not invest much time and resources on the periphery. Huge amounts of goods and funds flowed from west to east, to be invested in the Babylonian heartland. Local populations in Babylonia were hired by the temples, as well as by other institutions, to do the "king's work" (dulli šarri). Besides small groups of deportees and foreigners such as Egyptians, the vast majority of the labourers employed on the great Babylonian building projects were local Babylonians.

By ca. 585 BCE, the Neo-Babylonian Empire was able to maintain relative stability in both its core in its periphery. At the same time, the imperial rule started to increase its investments in the periphery in terms of time and resources. Major Babylonian temples received royal grants of agricultural lands outside Babylonia proper and were ordered to exploit these territories, thus increasing both the temples' and the crown's incomes. To that end, the temples had to utilize their own resources and personnel. The chronic manpower shortage that ensued led the temples to outsource the work to local rent farmers and hired labourers.

Besides additional income from taxation, the state received much-needed men for military service and corvée work, duties tied to grants of royal land. Furthermore, the temples' activity increased Babylonian presence in the periphery. While it is reasonable to assume that the Babylonian presence in the far west was primarily military and commercial in nature, rather than aimed at the establishment of simple agrarian colonies, the administrative mechanisms were nonetheless the same.

It should also be noted, however, that while this system allowed the crown to control vast territories and to put them to better use, at the same time it meant that often the palace had no direct control over these faraway lands. This in fact may have impaired the ability of the state to properly enforce its rule even after the realisation that more intrusive measures were needed. The outsourcing of control, which was taken up in order tighten the state's grip on the western territories, meant that the palace was now dependent on the temples to some degree. While this policy had no significant (negative) fiscal consequences, it may have had 
graver repercussions from the political and military perspective; namely, the overall stability of the Babylonian state and its ability to face the upcoming Persian threat.

The perception of little to no permanent Babylonian presence in the west has prevailed in research for many years. This was heavily influenced by the biblical narrative of the empty land on the one hand, and the difficulty in identifying archaeologically the relatively short period of Babylonian rule on the other. ${ }^{60}$ This, however, cannot be maintained. Although the Babylonian rule in the west was indeed, generally speaking, less intensive and intrusive than that of their Assyrians predecessors, the picture can now be fine-tuned. We can no longer speak of the Neo-Babylonian period as of a monolithic block, whereby the question of whether or not the Babylonians established a province in Judah is a litmus test for their overall foreign policy. ${ }^{61}$

The Neo-Babylonian short-lived rule in the west lasted for just 66 years. Unlike the earlier long, drawn-out process of the Neo-Assyrian takeover in the west from the ninth century onwards, or the Achaemenids' later rapid establishment of their imperial rule, it took the Neo-Babylonian Empire two decades to reach the west, and another two decades to stabilize it. Only then did they turn from an ad hoc approach to a proactive rule throughout the empire. The relative stability reached from the mid-reign of Nebuchadnezzar onwards nevertheless crumbled following his death in 562 BCE. Four kings ruled Babylonia in the next six years. The fourth, Nabonidus, remained on the throne for 17 whole years, but his reign is hardly an example of stability. Scholars are still baffled by his 10 years' sojourn in Tayma, a period during which his son, Belshazzar, was the active king. Although later sources, depicting Cyrus the Great marching into Babylon unchallenged and

60 See Zorn 2014 and the discussion in Faust 2012: 11-17 regarding the difficulty in identifying sixth century pottery assemblages.

61 The final loss of Judean sovereignty falls within the pivotal moment in the Babylonian imperial rule discussed in this paper, and the Babylonian attempt to maintain some form of a Judean political/administrative entity around Mizpah should probably be seen in this context. Unfortunately, there are little to no historical records regarding the fallout of the assassination of Gedaliah. Moreover, if the area was indeed considered by the Babylonians to be a kind of a buffer-zone, then the imperial policy in Judah cannot be simply extrapolated as representative of imperial rule in the western periphery. At the same time, we should also bear in mind that, while it is hard to date Nebuchadnezzar's rock inscriptions in Lebanon, the few hints we do have - especially regarding the Brisa inscription and, to a lesser extent, in Nahr el-Kalb - point to a relative late date towards the end of Nebuchadnezzar's reign (Da Riva 2012a, 2012b: 20); i.e. 15-20 years after the events in Judah. An interesting question for future research may then be whether or not the chronic problems in Judah from 597 onwards had any impact on the Babylonian perception of the border of their empire. Related to that would be the question of Edom, the (later) activity of Nabonidus, and the nature of the Babylonian involvement in the Transjordan region in general; see Crowell 2007 (with previous literature). 
happily welcomed by the populace, may be exaggerated (Waerzeggers 2015), it is clear that the Neo-Babylonian imperial power was not as solid as one might think; to put it bluntly, the Neo-Babylonian Empire was not very good at being an empire. The reasons for that are beyond the scope of this paper, although one may mention the Babylonian "self-centred" ethos, as well as the death of the charismatic Nebuchadnezzar after his 43 years' reign. We must also take into consideration, however, that the ad hoc approach and lack of sufficient and efficient control during the early years created an instable base on which the later, more intrusive policy was build. At that point, perhaps, it was too late.

\section{References}

Alstola, T. 2020. Judeans in Babylonia: A Study of Deportees in the Sixth and Fifth Centuries BCE. Culture and History of the Ancient Near East 109. Leiden/Boston: Brill.

André-Salvini, B. 2013. La tour de Babylone: Etudes et recherches sur les monuments de Babylone (actes du colloque du 19 avril 2008 au musée du Louvre, Paris). Roma: CNR - Consiglio Nazionale Ricerche.

Bagg, A. 2011. Die Assyrer und das Westland. Studien zur historischen Geographie und Herrschaftspraxis in der Levante im 1. Jt. v.u. Z. Leuven: Peeters.

Bagg, A. 2013. "Palestine under Assyrian Rule: a New Look at the Assyrian Imperial Policy in the West.” JAOS 133 (1): 119-44.

Baker, H. 2002. "Approaches to Akkadian Name-giving in First Millennium BC Mesopotamia." In Mining the Archives. Festschrift for Christopher Walker on the Occasion of his 60th Birthday, edited by C. Wunsch, 1-24. Dresden: ISLET. Babylonische Archive 1.

Barstad, H. M. 2003. "After the "Myth of the Empty Land": Major Challenges in the Study of NeoBabylonian Judah." In Judah and the Judeans in the Neo-Babylonian Period, edited by L. Oded, and J. Blenkinsopp, 3-20. Winona Lake: Eisenbrauns.

Beaulieu, P. A. 2005. "Eanna's contribution to the construction of the North Palace at Babylon.” In Approaching the Babylonian Economy. Proceedings of the START Project Symposium Held in Vienna, 1-3 July 2004, edited by H. Baker, and M. Jursa, 45-73. Münster: Ugarit-Verlag.

Becking, B. 2002. “West Semites at Tell Šēh Ḥamad: Evidence for the Israelite Exile?.” In Kein Land für sich allein. Studien zum Kulturkontakt in Kanaan, Israel/Palästina und Ebirnâri für Manfred Weippertzum 65. Geburtstag, edited by U. Hübner, and E. A. Knauf. Orbis Biblicus et Orientalis 186, 153-66. Freiburg: Universitätsverlag; Göttingen: Vandenhoeck \& Ruprecht.

Betlyon, J. W. 2003. "Neo-Babylonian Military Operations Other Than War in Judah and Jerusalem." In Judah and the Judeans in the Neo-Babylonian Period, edited by L. Oded, and J.

Blenkinsopp, 263-84. Winona Lake: Eisenbrauns.

Blenkinsopp, J. 2002. "The Bible, Archaeology and Politics; or, the Empty Land Revisited.” JSOT27: 169-87.

Brinkman J. A. 1990. "The Babylonian Chronicle Revisited.” In Lingering over Words, Studies in Ancient Near Eastern Literature in Honor of William L. Moran, edited by T. Abusch, J. Huehnergard, and P. Steinkeller, 73-104. Georgia: Scholars Press. 
Brinkman, J. A. 1993. "Babylonian Influence in the Šēh Ḥamad Texts Dated under Nebuchadnezzar II." $S A A B$ 7/3: 133-38.

Carter, E. C. 2003. "Ideology and Archaeology in the Neo-Babylonian Period: Excavating Text and Tell." In Judah and the Judeans in the Neo-Babylonian Period, edited by L. Oded, and J. Blenkinsopp, 301-22. Winona Lake: Eisenbrauns.

Crowell, B. L. 2007. "Nabonidus, as-Sila, and the Beginning of the End of Edom." BASOR 348: 7588.

Da Riva, R. 2002 Der Ebabbar-Tempel von Sippar in frü;hneubabylonischer Zeit (640-580 v. Chr) (AOAT 291), Münster.

Da Riva, R. 2008. The Neo-Babylonian Royal Inscriptions: An Introduction. Guides to the Mesopotamian Textual Record. GMTR, 4. Münster: Ugarit-Verlag.

Da Riva, R. 2012a. "Dynastic gods and favourite gods in the Neo-Babylonian period." In Concepts of Kingship in Antiquity, edited by. G. B. Lanfranchi, and R. Rollinger, 45-62. Padova: S.A.R.G.O.N. Editrice e Libreria.

Da Riva, R. 2012b. The Twin Inscriptions of Nebuchadnezzar at Brisa (Wadi esh-Sharbin, Lebanon): A Historical and Philological Study. AfO Bhft. 32. Vienna: Institut für Orientalistik der Universtität Wien.

Da Riva, R. 2013a. “Nebuchadnezzar Il's Prism (EŞ 7834): A New Edition.” Zeitschrift für Assyriologie und vorderasiatische Archäologie 103 (2): 196-229.

Da Riva, R. 2013b The Inscriptions of Nabopolassar, Amēl-Marduk and Neriglissar. SANER, 3. Berlin/Boston: De Gruyter.

Da Riva, R. 2014. "Enduring Images of an Ephemeral Empire: Neo-Babylonian Inscriptions and Representations in the Western Periphery." In Mesopotamia in the Ancient World: Impact, Continuities, Parallels, edited by R. Rollinger, and E. van Dongen. Melammu Symposia 7, 306-30. Münster: Ugarit-Verlag.

Da Riva, R. 2018. “The Neo-Babylonian Palace as Centre of the World.” ARAMAZD: Armenian Journal of Near Eastern Studies 12 (1): 96-108.

Da Riva, R. 2019. "The king of the rock revisited: the site of As-Sila (Tafila, Jordan) and the Iscription of Nabonidus of Babylon." In A Tribute to Mirjo Salvini, edited by R. Eichmann, H. Schaudig, and A. Hausleiter, 163-76. Oxford: Archaeopress.

Eichmann, R., H. Schaudig, and A. Hausleiter. 2006. “Archaeology and Epigraphy at Tayma (SaudiArabia)." Arabian Archaeology and Epigraphy 17: 163-76.

Eph'al, I. 1979. "Assyrian Domination in Palestine.” In The Age of the Monarchies: Political History, edited by A. Malamat, 276-89. Jerusalem: Massada.

Fales, M. 1993. "West Semitic Names in the Šēh Ḥamad Texts." SAAB 7/3: 139-50.

Fantalkin, A. 2011. "Why Did Nebuchadnezzar II Destroy Ashkelon in Kislev 604 B.C.E.?.” In The Fire Signals of Lachish: Studies in the Archaeology and History of Israel in the Late Bronze Age, Iron Age, and Persian Period in Honor of David Ussishkin, edited by I. Finkelstein, and N. Na'aman, 87-111. Winona Lake: Eisenbrauns.

Fantalkin, A. 2018. "Neo- Assyrian Involvement in the Southern Coastal Plain of Israel: Old Concepts and New Interpretations." In The Southern Levant under Assyrian Domination, edited by S. Z. Aster, and A. Faust, 162-85. Winona Lake: Eisenbrauns.

Faust, A. 2007. "Settlement Dynamics and Demographic Fluctuations in Judah from the Late Iron Age to the Hellenistic Period and the Archaeology of Persian-Period Yehud." In A Time of Change: Judah and its Neighbors During the Persian and Early Hellenistic Periods, edited by Y. Levin, 23-51. London: Bloomsbury. 
Faust, A. 2011. "Deportation and Demography in Sixth-Century B.C.E. Judah.” In Interpreting Exile: Interdisciplinary Studies of Displacement and Deportation in Biblical and Modern Contexts, eds. B. E. Kelle, F. A. Ritchel, and J. L. Wright. SBL Ancient Israel and its Literature 10. Atlanta: SBL.

Faust, A. 2012. Judah in the Neo-Babylonian Period The Archaeology of Desolation. Atlanta: SBL. Fuchs, A. 2014. "Die unglaubliche Geburt des neubabylonischen Reiches oder: Die Vernichtung einer Weltmacht durch den Sohn eines Niemand." In Babylonien und seine Nachbarn in neuund spätbabylonischer Zeit Wissenschaftliches Kolloquium aus Anlass des 75. Geburtstages von Joachim Oelsner, Jena 2. und 3. März 2007, edited by M. Krebernik, and H. Neumann, 25-71. Münster: Ugarit-Verlag.

Glassner, J. J 2004. Mesopotamian Chronicles. Atlanta: SBL.

Grayson, A. K. 1975. Assyrian and Babylonian Chronicles. Locust Valley. NY: J.J. Augustin Publisher.

Hackl, J., and M. Jursa 2015. "Egyptians in Babylonia in the Neo-Babylonian and Achaemenid Periods." In Exile and Return: The Babylonian Context, edited by J. Stökl, and C. Waerzeggers, 157-80. Berlin/Boston: De Gruyter.

Horowitz, W. 1998. Mesopotamian Cosmic Geography. Winona Lake: Eisenbrauns.

Janković, B. 2013. Aspects of Urukean Agriculture in the First Millennium BC. PhD diss: University of Vienna.

Jursa, M. 1995 Die Landwirtschaft in Sippar in neubabylonischer Zeit. AfO Bhft, 25. Vienna: Institut für Orientalistik der Universtität Wien.

Jursa, M. 2005. Neo-Babylonian Legal and Administrative Documents: Typology, Contents and Archives. GMTR 1. Münster: Ugarit-Verlag.

Jursa, M. 2007. “Texte aus dem "Palastarchiv” Nebukadnezars, außerhalb von Berlin." NABU 2007/54.

Jursa, M. 2010a. Aspects of the Economic History of Babylonia in the First Millennium BC. Economic Geography, Economic Mentalities, Agriculture, the Use of Money and the Problem of Economic Growth. With contributions by J. Hackl, B. Janković, K. Kleber, E.E. Payne, C. Waerzeggers and M. Weszeli. AOAT 377. Münster: Ugarit-Verlag.

Jursa, M. 2010b. "Der neubabylonische Hof." In Der achaimenidische Hof / The Achaemenid Court. Akten des 2. Internationalen Colloquiums zum Thema Vorderasien im Spannungsfeld klassischer und altorientalischer Überlieferungen, Landgut Castelen bei Basel, 23.-25. Mai 2007, edited by B. Jacobs, and R. Rollinger. Classica et Orientalia 2, 67-106. Wiesbaden: Harrassowitz.

Jursa, M. 2014a. "The Lost State Correspondence of the Babylonian Empire as Reflected in Contemporary Administrative Letters." In State Correspondence in the Ancient World, edited by K. Radner, 94-111, 226-28. Oxford: Oxford University Press.

Jursa, M. 2014b. “The Neo-Babylonian Empire." In Imperien und Reiche in der Weltgeschichte. Epochenübergreifende und globalhistorische Vergleiche, edited by M. Gehler, and R. Rollinger, 121-48. Wiesbaden: Harrassowitz.

Jursa, M. 2015. "Labor in Babylonia in the First Millennium." In Labor in the Ancient World, edited by P. Steinkeller, and M. Hudson, 345-96. Dresden: ISLET.

Jursa, M., and S. Gordin. 2018. "The Ousting of the Nūr-Sîns: Micro-Historical Evidence for StateBuilding at the Neo-Babylonian Empire's Augustan Threshold." HEBAI 7: 42-64.

Jursa, M., J. Hackl, and M. Schmidl. 2014. Spätbabylonische Privatbriefe. AOAT 414/1, SbB 1. Münster: Ugarit-Verlag.

Jursa, M., and K. Wagensonner. 2014. "The Estates of Šamaš on the Hābūr.” In Extraction \& Control: Studies in Honor of Matthew W. Stolper, edited by M. Kozuh, W. F. M Henkelman, C. E. 
Jones, and C. Woods. SAOC, 68, 109-30. Chicago: The Oriental Institute of the University of Chicago.

Jursa, M., and R. Zadok. 2020. "Judeans and other Westsemites: another view from the Babylonian countryside." HEBAI 9 (1):20-40.

Kahn, D. 2018. "Nebuchadnezzar and Egypt: An Update on the Egyptian Monuments." HEBAI 7: 65-78.

Katzenstein, J. H. 1973. The History of Tyre. From the Beginning of the Second Millennium B.C.E. until the Fall of the Neo-Babylonian Empire in 538 B.C.E. Jerusalem: Schocken Institute for Jewish Research.

Killebrew, A. E., and M. Steiner, eds. 2014. In The Oxford Handbook of the Archaeology of the Levant: c. 8000-332 BCE. Oxford: Oxford University press.

Kleber, K. 2008. Tempel und Palast. Die Beziehungen zwischen dem König und dem Eanna-Tempel im spätbabylonischen Uruk. AOAT 358. Münster: Ugarit-Verlag.

Kreppner, F. J. 2008a. "The Collapse of the Assyrian Empire and the Continuity of Ceramic Culture: The Case of the Red House at Tall Sheikh Hamad." JANES 45: 147-65.

Kreppner, F. J. 2008b. "The Continuity of Ceramic Production after the Fall of the Neo-Assyrian Empire. New Data from the Red House of Tall Sheikh Hamad." In Proceedings of the 4th International Congress of the Archaeology of the Ancient Near East, edited by H. Kühne, R. Czichon, and F. J. Kreppner, 167-78. Wiesbaden: Harrassowitz.

Kühne, H. 1993. "Vier spätbabylonische Tontafeln aus Tall Šēh Ḥamad.” SAAB 7/3: 75-107.

Kühne, H. 1995. "The Assyrians in the Middle Euphrates and the Habur." In Neo-Assyrian Geography, edited by M. Liverani, 69-85. Quaderni di geografia storica, 5. Rome: Università di Roma La Sapienza.

Lemaire, A. 2003. "Nabonidus in Arabia and Judah in the Neo-Babylonian Period." In Judah and the Judeans in the Neo-Babylonian Period, edited by O. Lipschits and J. Blenkinsopp, 285-98. Winona Lake: Eisenbrauns.

Levavi, Y. 2017. "Betting on the right horse - loyalty in the early years of the Neo-Babylonian Empire." In Proceedings of the 60th Rencontre Assyriologique Internationale (Wasaw 2010, July 21-25, 2014): Fortune and Misfortune, edited by O. Drewnowska, and M. Sandowicz, 177-90. Winona Lake: Eisenbrauns.

Levavi, Y. 2018. Administrative Epistolography in the Formative Phase of the Neo-Babylonian Empire. dubsar 3, SbB 2. Münster: Zaphon.

Levavi, Y. In press. "The Sound of Silence: the Destruction of Babylon by Sennacherib and the Babylonian Chronicles." In Culture of defeat: Submission in written sources and the Archaeological record of the Ancient Near East, edited by K.Streit, and M.Grohmann. The Gorgias Studies in the Ancient Near East Series 165-187. Piscataway (N)): Gorgias.

Lipschits, O., and D. Vanderhooft. 2014. "Continuity and Change in the Persian Period Judahite Stamped Jar Administration." In Jewish "Material" Otherness? Studies in the Formation of Persian Period Judaism(s), edited by C. Frevel, K. Pyschny, and I. Cornelius. OBO 264, 43-66. Fribourg: Academic Press Fribourg.

Lipschits, O., and J. Blenkinsopp, eds. 2003. In Judah and the Judeans in the Neo-Babylonian Period. Winona Lake: Eisenbrauns.

Lipschits, 0. 2003. "Demographic Changes in Judah between the Seventh and the Fifth Centuries b.c.e." In Judah and the Judeans in the Neo-Babylonian Period, edited by 0 . Lipschits and J. Blenkinsopp, 323-76. Winona Lake: Eisenbrauns.

Lipschits, 0. 2011. "Shedding New Light on the Dark Years of the "Exilic Period": New Studies, Further Elucidation, and Some Questions Regarding the Archaeology of Judah as an 'Empty 
Land'." In Interpreting Exile: Displacement and Deportation in Biblical and Modern Contexts, edited by E. BradKelle, F. R Ames, and J. L. Wright. SBL Ancient Israel and its Literature 10, 57-90. Atlanta: SBL.

Livingstone, A. 2005. "Taimā’ and Nabonidus: It's a small world." In Writing and ancient Near Eastern society: Papers in honour of Alan R. Millard, edited by P. Bienkowski, C. Mee, and E. Slater. Journal for the Study of the Old Testament, Supplement Series 426, 29-39. London: T\&T Clark International.

MacDonald, M. C. A. 1997. "Trade Routes and Trade Goods at the Northern End of the 'Incense Road' in the First Millennium b.c." In Profumi d'Arabia: Atti del convegno, edited by A. Avanzini, 333-49. Saggi di storia antica, 11. Rome: L'Erma di Bretschneider.

Magee, P. 2014. The Archaeology of Prehistoric Arabia: Adaptation and Social Formation from the Neolithic to the Iron Age. Cambridge: Cambridge University Press.

Münkler, H. 2007 Empires: the Logic of World Domination from Ancient Rome to the United States. translated by Camiller, Patrick. Cambridge: Polity Press.

Nevader, M. 2015. “On Reading Ezekiel by the Rivers of Babylon.” Die Welt Des Orients 45/1: 99_ 110.

Oded, B. 2003. "Where Is the "Myth of the Empty Land" To Be Found? History versus Myth." In Judah and the Judeans in the Neo-Babylonian Period, edited by O. Lipschits, and J. Blenkinsopp, 55-74. Winona Lake: Eisenbrauns.

Oelsner, J. 2017. “Überlegungen zu Ausgrabungen von Babylon.” ZDMG 167: 289-94.

Pearce, L., and C. Wunsch. 2014 Documents of Judean Exiles and West Semites in Babylonia in the Collection of David Sofer. CUSAS, 28. Bethesda: CDL Press.

Pedersén, 0. 2005b. "Foreign Professionals in Babylon: Evidence from the Archive in the Palace of Nebuchadnezzar II." In Ethnicity in Ancient Mesopotamia: Papers Read at the 48th Rencontre Assyriologique Internationale, Leiden, 1-4 July 2002, edited by W. H. van Soldt, Kalvelagen, R., and D. Katz. PIHANS 102, 267-72. Leiden: Nederlands Instituut voor het Nabije Oosten.

Pedersén, 0. 2009. “Neo-Assyrian Texts from Nebuchadnezzar's Babylon: A preliminary Report." In OfGod(s), Trees, Kings, and Scholars: Neo-Assyrian and Related Studies in Honour of Simo Parpola, edited by M. Luukko, S. Svärd, and R. Mattila. Studia Orientalia 106, $193-99$. Helsinki: The Finnish Oriental Society.

Pedersén, O. 1998. Archives and Libraries in the Ancient Near East 1500-300 B.C. Bethesda: CDL Press.

Pedersén, 0. 2005a. Archive und Bibliotheken in Babylon: Die Tontafeln der Grabung Robert Koldeweys 1899-1917. Abhandlungen der Deutschen Orient-Gesellschaft 25, Saarbrücken: Saarländische Druckerei und Verlag.

Postgate, N. J. 1993. "The Four “Neo-Assyrian” Tablets from Šèh Ḥamad.” SAAB 7/3: 109-24. Radner, K. 2002. Die neuassyrischen Texte aus Tall Šêh Ḥamad: Mit Beiträgen von Wolfgang Röllig zu den aramäischen Beischriften. Berlin: Reimer.

Radner, K. 2019. "Last Emperor or Crown Prince Forever? Aššur-uballiț II of Assyria according to Archival Sources." In Neo-Assyrian Sources in Context: Thematic Studies of Texts, History and Culture. SAAS 28, edited by S. Yamada, 135-42. Winona: Eisenbrauns.

Raz, E., T. Raz, and A. Uchitel. 2001. "The Rock of Edom.” Cathedra 101: 19-38. (in Hebrew).

Rubio, G. 2009. "Scribal secrets and antiquarian nostalgia: Tradition and scholarship in Ancient Mesopotamia." In Reconstruyendo el pasado remoto. Estudios sobre el Próximo Oriente Antiguo en homenaje a Jorge R. Silva Castillo. Reconstructing a Distant Past. Ancient Near Eastern Essays in Tribute to Jorge R. Silva Castillo, edited by D. A. B Fracaroli, and G. del Olmo Lete, 155-82. Sabadell: Ausa. 
Sack, R. H. 2003. "Nebuchadnezzar II and the Old Testament: History versus Ideology." In Judah and the Judeans in the Neo-Babylonian Period, edited by O. Lipschits, and J. Blenkinsopp, 221-34. Winona Lake: Eisenbrauns.

Sack, R. H. 2004. Images of Nebuchadnezzar: The Emergence of a Legend, 2nd edition Susquehanna: University Press. London/Toronto: Associated University Press.

Schaudig, H. 2001. Die Inschriften Nabonids von Babylon und Kyros des Grossen samt den in ihrem Umfeld entstandenen Tendenzschriften Textausgabe und Grammatik. AOAT, 526. Münster: Ugarit-Verlag.

Schaudig, H. A. 2016. "Rock Relief and Cuneiform Inscription of King Nabonidus at al-Ḥā'iț (Province of Ḥā'il, Saudi Arabia), Ancient Padakku.” Zeitschrift für Orient-Archäologie 9: 224-40.

Still, B. 2019. The Social World of Babylonian Priests. Culture and History of the Ancient Near East 109. Leiden/Boston: Brill.

Van der Brugge, C., and K. Kleber. 2016. "The Empire of Trade and the Empires of Force: Tyre in the Neo-Assyrian and Neo-Babylonian Periods." In Dynamics of Production and Economic Interaction in the Near East in the First Half of the First Millennium BCE, edited by J. C. M Garcia, 187-222. Oxford: Oxbow.

Vanderhooft, D. 1999 The Neo-Babylonian Empire and Babylon in the Latter Prophets. Harvard Semitic Monographs, 59. Atlanta: Scholars Pres.

Vanderhooft, D. 2003. "Babylonian Strategies of Imperial Control in the West: Royal Practice and Rhetoric." In Judah and the Judeans in the Neo-Babylonian Period, edited by O. Lipschits, and B. Jacobs, 235-62. Winona Lake: Eisenbrauns.

Vanderhooft, D. 2018. "Nebuchadnezzar, King of Babylon, My Servant: Contrasting Prophetic Images of the Great King." HEBAI 7: 93-111.

Waerzeggers, C. 2010. "Babylonians in Susa - The Travels of Babylonian Businessmen to Susa Reconsidered." In Der Achämenidenhof- Akten des 2. Internationalen Kolloquiums zum Thema Vorderasien im Spannungsfeld klassischer und altorientalischer Überlieferungen, edited by B. Jacobs, and R. Rollinger, 777-813. Wiesbaden: Harrassowitz Verlag.

Waerzeggers, C. 2012. “The Babylonian Chronicles: Classification and Provenance." JNES 71 (2): 285-98.

Waerzeggers, C. 2014. Marduk-rēmanni: Local Networks and Imperial Politics in Achaemenid Babylonia. OLA, 233. Leuven: Peeters.

Waerzeggers, C. 2015. "Babylonian Kingship in the Persian Period: Performance and Reception." In Exile and Return: The Babylonian Context, edited by J. Stökl, and C. Waerzeggers, 181-222. Berlin/Boston: De Gruyter.

Zadok, R. 1981. "Arabians in Mesopotamia during the Late Assyrian, Chaldean, Achaemenian and Hellenistic Periods Chiefly According to the Cuneiform Sources." Zeitschrift der Deutschen Morgenländischen Gesellschaft 131: 42-84.

Zadok, R. 2013. "The Onomastics of the Chaldean, Aramean, and Arabian Tribes in Babylonia during the First Millennium." In Arameans, Chaldeans, and Arabs in Babylonia and Palestine in the First Millennium B.C., edited by A. Berlejung, and M. Streck, 261-336. Wiesbaden: Harrassowitz.

Zawadzki, S., 2010. "The Portrait of Nabonidus and Cyrus in Their(?) Chronicle: When and Why the Present Version Was Composed." In Who Was King? Who Was Not King? The Rulers and Ruled in the Ancient Near East, edited by P. Charvát, and P. M. Vlčková, 142-54. Prague: Institute of Archaeology of the Academy of Sciences of the Czech Republic. 
Zertal, A. 2003. "The Province of Samaria (Assyrian Samerina) in the Late Iron Age (Iron Age III).” In Judah and the Judeans in the Neo-Babylonian Period, edited by O. Lipschits, and J. Blenkinsopp, 377-412. Winona Lake: Eisenbrauns.

Zorn, R. J. 2003. "Tell en-Naßbeh and the Problem of the Material Culture of the Sixth Century." In Judah and the Judeans in the Neo-Babylonian Period, edited by O. Lipschits, and J. Blenkinsopp, 413-47. Winona Lake: Eisenbrauns.

Zorn, R. J. 2014. "The Levant During the Babylonian Period." In The Oxford Handbook of the Archaeology of the Levant: c. 8000-332 BCE, edited by A. E. Killebrew, and M. Steiner, 825-40. Oxford: Oxford University press. 